\title{
A plan for online teaching and learning for the Master of Applied Indigenous Knowledge (MAIK) programme in Māngere: Responding to COVID-19
}

\section{Introduction}

First, this paper will explain the Master of Applied Indigenous Knowledge (MAIK) programme. Second, this article will describe COVID-19. Third, this paper will outline the impacts on COVID-19 on tertiary education. Fourth, and finally, this article will present and explain the MAIK online learning plan that we are using from March to teach the MAIK programme in response to COVID-19.

\section{MAIK programme}

MAIK is a programme that acknowledges the expertise of Indigenous practitioners in particular fields of knowledge and guides them through the process of writing a 15,000-20,000-word Exegesis and completing a practice and research-based Project that meaningfully contributes to the development of their Indigenous communities. 
The programme aims to inspire graduates to demonstrate the following:

- Show evidence of advanced knowing in a specialist area of Indigenous Knowledge

- Understand and apply sophisticated theoretical knowledge including Māori principles and philosophies (or other Indigenous equivalent )

- Critically evaluate the findings and discussions from relevant literature and life experience

- Rangahau, analyse and wānanga from evidence

- Independently self-reflect on all aspects of learning and practice

- Transfer and apply knowledge to new situations

- Engage in rigorous intellectual analysis, critique, and problem solving

- Contribute to an Indigenous community through completion of a community-based project; provide leadership within a specific field, and modelling of principle-based practice

- Pursue lifelong learning, either community based or at a doctoral level within a field of Indigenous knowledge

- Pursue individual excellence for collective success, generating a holistic methodology (Te Wānanga o Aotearoa, 2019, p. 8).

MAIK is made up of five papers known as Kōnae Ako. There are four papers in year one and one paper in the second and final year. The Kōnae Ako are as follows:

\section{Mōhiotanga-Experience and Knowledge Production (Year 1)}

In this kōnae ako tauira will explore the nature of knowledge (epistemology) and critically evaluate the way that tacit knowledge (knowing gained through direct experience) influences practice. Tauira will examine the 
intergenerational transfer of traditional knowledge and the preservation of Indigenous ways of knowing and will position themselves as Indigenous practitioners within their specialised field of practice. At the completion of this kōnae ako, tauira will develop and present a holistic model of understanding that reflects their practice (Te Wānanga o Aotearoa, 2019, p. 12).

\section{Mātauranga-Thought and Knowledge Production (Year 1)}

In this kōnae ako, tauira will deconstruct their practice with reference to underlying Māori/ Indigenous principles and values, and compare and contrast these with other Indigenous practitioners. Tauira will critically evaluate a range of Indigenous models/ frameworks related to Indigenous thought and develop their own distinctive principle-based model of practice (Te Wānanga o Aotearoa, 2019, p. 23).

\section{Māramatanga-Wisdom and Knowledge Production (Year 1)}

This kōnae ako will provide tauira with the skills and knowledge to formulate and interpret values and ideas of knowledge through philosophical inquiry. Tauira will explore philosophy with the intent of critiquing ethical issues, logic and debates about the nature of indigeneity. In this kōnae ako, tauira will synthesise information from literary, oral and/or visual sources to support a Māori/Indigenous philosophical position that relates to field of practice (Te Wānanga o Aotearoa, 2019, p. 34).

\section{Mauri Ora-Well-being, Knowing and Transformation (Year 1)}

In this kōnae ako, tauira will design an Indigenous community-based rangahau project that will be implemented in Kōnae Ako 5. This kōnae focuses on specific aspects of Indigenous rangahau design including the selection of a relevant rangahau topic, constructing pertinent rangahau questions, identifying appropriate 
rangahau approaches, and outlining the tikanga rangahau (ethical) considerations associated with Indigenous rangahau. Tauira will develop a Kaupapa Proposal and complete a Tikanga Rangahau (ethics) application as part of this kōnae ako (Te Wānanga o Aotearoa, 2019, p. 43).

\section{Maumaharatanga-Applied Indigenous Knowledge, Project and Exegesis (Year 2)}

This kōnae ako is the pinnacle of tauira knowledge and practices in He Waka Hiringa: Master of Applied Indigenous Knowledge. It provides the vehicle to apply and evaluate learning within the context of an applied project connected to indigenous epistemology and an indigenous community. At the end of the konae, tauira will present their taonga tuku iho and communicate the findings of their projects. Tauira will also produce a written report (an exegesis) as part of this final kōnae ako (Te Wānanga o Aotearoa, 2019, p. 53).

In line with Māori and Indigenous values, the MAIK degree is normally delivered face-to-face through noho marae (five-day teaching and learning intensives) along with weekly tutorials. However, the growing impacts of COVID-19 will change the way the programme is delivered as the world comes to terms with using and developing new ways of teaching and learning.

\section{COVID-19}

COVID-19, as it has been named by the World Health Organization, comes from the same group of viruses that caused SARS-severe acute respiratory syndrome-and MERS-Middle East respiratory syndrome (Hageman, 2020). Coronaviruses are common around the world and are named for their crown-like "surface projections" (Hageman, 2020). It is recognised that COVID-19 started in Wuhan, China, and has been 
connected to an animal market there, inferring zoonotic ${ }^{1}$ origins (Hageman, 2020; Koenig et al., 2020; Sun et al., 2020; H. Wang et al., 2020; Xiao et al., 2020). Viruses like COVID-19, Hageman (2020) argues, are "host specific and can infect humans and a variety of different animals as well" (p. 99). COVID-19 presents as "fever, nonproductive cough, and respiratory distress" (Hageman, 2020 , p. 99). In addition to the symptoms listed by Hageman (2020), H. Wang et al. (2020) opine that "[p]atients have clinical manifestations, including fever, cough, shortness of breath, muscle ache, confusion, headache, sore throat, rhinorrhoea [runny nose], chest pain, diarrhea, and nausea and vomiting" (p. 1).

Negahdaripour (2020) asserts that "implementing preventive strategies and the collaboration of countries around the globe are of the utmost importance to lower the threat of COVID-19" (p. 82). Concerning the control of COVID-19 transmission, Anderson et al. (2020) contend:

Individual behaviour will be crucial to control the spread of COVID-19. Personal, rather than government action, in western democracies might be the most important issue. Early self-isolation, seeking medical advice remotely unless symptoms are severe, and social distancing are key. Government actions to ban mass gatherings are important, as are good diagnostic facilities and remotely accessed health advice, together with specialised treatment for people with severe disease (p. 3).

Some governments have issued strict containment measures such as closing borders (Lautensach, 2020). Also, the development of a vaccine has begun in some countries (Anderson, et al., 2020; McAleer, 2020).

\footnotetext{
${ }^{1}$ Referring to diseases transferred from animals to humans (Shao et al., 2011).
} 
However, "[n]o vaccine or effective antiviral drug is likely to be available soon" as this "will take time and we are probably a least 1 year to 18 months away from substantial vaccine production" (Anderson et al., 2020, p. 2).

To reduce the spread of the virus, The World Health Organization (2020) recommends that all people follow good hand and respiratory hygiene, maintain social distance, avoid touching mouth and nose, and selfisolation if sick. With this in mind, as well as the responses within the tertiary education sector internationally and nationally, our Auckland-based programme moved quickly to prepare to teach MAIK online.

\section{COVID-19 and tertiary education}

On Saturday 21 March, Prime Minister Jacinda Ardern announced a four-level COVID-19 alert system. As of 21 March, our country was placed at Level 2. As a result of the developing COVID-19 situation and accelerated by the Prime Minister's announcement of the alert system, universities and other tertiary institutions around the country are very quickly developing plans for moving to online learning. 


\begin{tabular}{|c|c|}
\hline LEVEL & RISKASSESSMENT \\
\hline $\begin{array}{l}\text { Level } 4 \text { - Eliminate } \\
\text { Likely that disease } \\
\text { is not contained }\end{array}$ & $\begin{array}{l}\text { - Sustained and intensiviv transmission } \\
\text { Widespread outbreaks }\end{array}$ \\
\hline $\begin{array}{l}\text { Level } 3 \text { - Restrict } \\
\text { Heightened risk that } \\
\text { disease is not contained }\end{array}$ & $\begin{array}{l}\text { - Community transmission occurring OR } \\
\text { Mutiple clusters break out }\end{array}$ \\
\hline $\begin{array}{l}\text { Level } 2 \text { - Reduce } \\
\text { Disease is contained, } \\
\text { but risks of community } \\
\text { transmission growing }\end{array}$ & 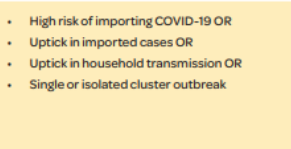 \\
\hline $\begin{array}{l}\text { Level } 1 \text { - Prepare } \\
\text { Disease is } \\
\text { contained }\end{array}$ & $\begin{array}{l}\text {. Heightened risk of fimporting Covo-19 OR } \\
\text { Sporadici importec cases OR } \\
\text { isolated household transmission associated } \\
\text { with imported cases }\end{array}$ \\
\hline
\end{tabular}

Figure 1. New Zealand COVID-19 alert levels (adapted from Unite against COVID-19, 2020, 21 March, n.p.).

Houlden and Veletsianos (2020, Mar 13) maintain that COVID-19 will force universities to switch to online classes. The virus, they argue, "has revealed vulnerabilities in post-secondary systems around the world" (n.p.). Certainly, it is apparent that "society needs flexible and resilient education systems as we face unpredictable futures" (Houlden \& Veletsianos, 2020, Mar 13, n.p.). The unfolding COVID-19 situation provides for educators "a chance to carefully examine educational technology in acute, crisis-driven contexts" (Houlden \& Veletsianos, 2020, Mar 13, n.p.). Houlden and Veletsianos (2020, Mar 13) assert that although the shift to online teaching and learning will result in a "massive increase in working hours", at least initially, the outcomes "for some educators and some students so far are promising" (n.p.). Indeed, the following three 
considerations about the shift to online learning, identified by Houlden \& Veletsianos (2020, Mar 13), are relevant to MAIK:

- Effective adaption to rapidly changing circumstances

- Preparedness

- A willingness to collaborate and offer care and support.

\section{MAIK plan for online learning}

As a result of the burgeoning COVID-19 situation, the Auckland-based Kaiako of the MAIK programme taught at Te Wānanga o Aotearoa in Māngere are prepared to move many aspects of the programme online-a decision based on international trends, research, and the abovementioned announcement from Prime Minister Jacinda Ardern. In line with Houlden and Veletsianos (2020, Mar 13) we are effectively adapting to rapidly changing circumstances, we are in a constant state of preparation, and we are more than willing to collaborate and offer care and support to our Tauira in new ways.

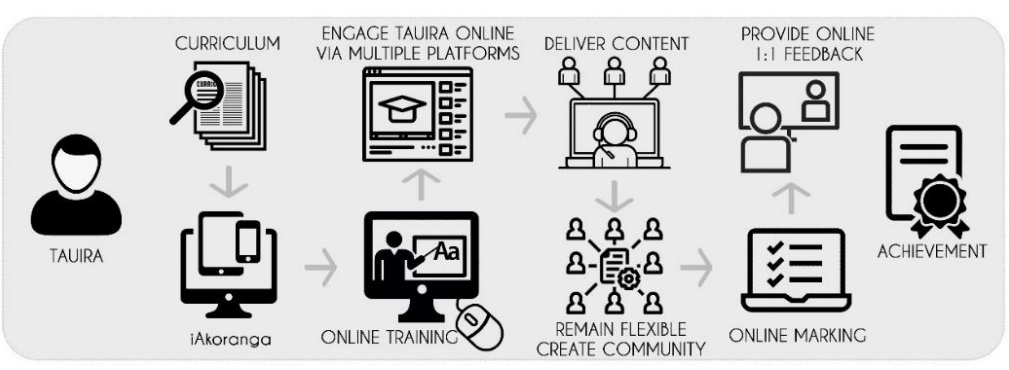

Figure 2. MAIK Online Learning Plan 
The MAIK online learning plan begins with the Tauira and ends with Tauira achievement. The following are the steps we will take to ensure Tauira achievement and success:

\section{Curriculum}

Kaiako will ensure that curriculum requirements and learning outcomes are expressed online in novel, innovative, and appropriate ways.

\section{iAkoranga (Moodle)}

Kaiako will upload content to iAkoranga-a rebranded version of Moodle-and will create learning activities that engage Tauira. Moodle allows for a range of activities-those relevant to MAIK have been included in the list below-to take place online. We will use these activities to support and enhance the learning of our Tauira:

\section{Assignments}

Enable teachers to grade and give comments on uploaded files and assignments created on and off line

\section{Chat}

Allows participants to have a real-time synchronous discussion

\section{Choice}

A teacher asks a question and specifies a choice of multiple responses

\section{Database}

Enables participants to create, maintain and search a bank of record entries

\section{Feedback}

For creating and conducting surveys to collect feedback 


\section{Forum}

Allows participants to have asynchronous discussions

\section{Glossary}

Enables participants to create and maintain a list of definitions, like a dictionary

\section{Lesson}

For delivering content in flexible ways

\section{Quiz}

Allows the teacher to design and set quiz tests, which may be automatically marked and feedback and/or to correct answers shown

\section{Survey}

For gathering data from students to help teachers learn about their class and reflect on their own teaching

\section{Workshop}

Enables peer assessment (Moodle, 2019, 28 December, n.p.).

\section{Online training}

Kaiako will provide Tauira with ongoing support and training around how to use iAkoranga effectively to support and enhance learning. As other online platforms are engaged with, Kaiako will disseminate knowledge and training to Tauira to prepare them for learning in new ways.

\section{Deliver content}

Kaiako will deliver content to Tauira and teach using online platforms such as Zoom, Facebook live, Google Classrooms, YouTube channels, and other ways. Of course, iAkoranga, is likely to remain as the base platform of online learning for the MAIK programme. 


\section{Remain flexible \& create community}

Kaiako will remain flexible to changing circumstances and will adapt delivery modes and methods as circumstances dictate without compromising learning outcomes. Kaiako and Tauira will build an online learning community where learning outcomes are achieved and celebrated.

\section{Online marking}

Kaiako will receive assessments from Tauira via iAkoranga. Tauira will receive results-including assessment with Tracking Changes notes and a completed marking schedule-via iAkoranga. Concerning the requirement for in-class presentations, these will be substituted with recorded presentations; Tauira may use their preferred method of recording their presentations which will then be submitted via iAkoranga.

\section{Provide online 1:1 feedback}

Kaiako will provide $1: 1$ feedback to Tauira via Zoom and in other ways. Ongoing feedback and communication will be critical to ensuring Tauira achievement.

\section{Conclusion}

This paper explained the MAIK programme. This article described COVID-19. This paper outlined the effects of COVID-19 on tertiary education. Finally, this paper presented and explained the MAIK online learning plan that we are using from March 2020 to teach the MAIK programme in response to COVID-19. As the effects of COVID-19 are becoming more apparent, the tertiary education sector needs to prepare to respond to shifting circumstances to ensure that Tauira continue to achieve despite the global pandemic crisis. While there is no certainty around how long COVID-19 will impact upon tertiary education, the silver lining for MAIK is that we have been pushed to discover and employ different ways of teaching and learning and in so doing we expand our 
teaching practice and prepare ourselves for the future of tertiary education. 


\section{References}

Anderson, R. M., Heesterbeek, H., Klinkenberg, D. \& Hollingsworth, T. D. (2020). How will country-based mitigation measures influence the course of the COVID-19 epidemic? The Lancet. https://doi.org/10.1016/S0140-6736(20)30567-5

Hageman, J. R. (2020). The coronavirus disease 2019 (COVID-19). Pediatric Annals, 49(3), 99-100. http:/ /dx.doi.org/10.3928/19382359-20200219-01

Houlden, S. \& Veletsianos, G. (2020, 13 March). COVID19 pushes universities to switch to online classes-but are they ready? The Conversation. Retrieved from https://theconversation.com/covid-19-pushes-

universities-to-switch-to-online-classes-but-are-theyready-

132728?fbclid=IwAR0LLAUo4egQSJ1Izax2S_XCeuxCsVOA0M2zHnoWLPlogclvVpLohZQThA

Koenig, K. L., Bey, C. K., \& McDonald, E. C. (2020). 2019nCoV: The identify-isolate-inform (3I) tool applied to a novel emerging coronavirus. The Western Journal of Emergency Medicine, 21(2). Retrieved from https://search.proquest.com/docview/2375800992? accountid $=44427$

Lautensach, S. (2020). Editorial 2020. Journal of Human Security, 16(1), $1-2$. http://dx.doi.org/10.12924/johs2020.16010001

McAleer, M. (2020). Prevention is better than the cure: Risk management of COVID-19. Journal of Risk and Financial Management, 13(3), 46. http://dx.doi.org/10.3390/jrfm13030046

Moodle (2019, 28 December). Activities. https://docs.moodle.org/38/en/Activities

Negahdaripour, M. (2020). The battle against COVID-19: Where do we stand now? Iranian Journal of Medical Sciences, 45(2), 81-82. http://dx.doi.org/10.30476/ijms.2020.46357

Shao, D., Shi, Z., Wei, J. \& Ma, Z. (2011). A brief review of foodborne zoonoses in China. Epidemiology and 
Infection, 139(10), 1497-1504. http://dx.doi.org/10.1017/S0950268811000872 Sun, Z., Thilakavathy, K., Kumar, S. S., He, G. \& Liu, S. V. (2020). Potential factors influencing repeated SARS outbreaks in China. International Journal of Environmental Research and Public Health, 17(5), 1633. http://dx.doi.org/10.3390/ijerph17051633

Te Wānanga o Aotearoa (2019). He Waka Hiringa: Master of Applied Indigenous Knowledge, MAIK801 \& 901, Marau 2019.

Unite against COVID-19. (2020, 21 March ). COVID-19 alert system. https://covid19.govt.nz/governmentactions/covid-19-alert-system/

Wang, H., Wang, Z., Dong, Y., Chang, R., Xu, C., Yu, X., Zhang, S., Tsamlag, L., Shang, M., Huang, J., Wang, Y., Xu, G., Shen, T., Zhang, X \& Cai, Y. (2020). Phaseadjusted estimation of the number of coronavirus disease 2019 cases in Wuhan, China. Cell Discovery, 6(1). http://dx.doi.org/10.1038/s41421020-0148-0

World Health Organization (2020). Basic protective measures against the new coronavirus. https://www.who.int/emergencies/diseases/novelcoronavirus-2019/advice-for-public

Xiao, W. X., Xiao, X. W., Xian, G. J., Kai, J. X., Ling, J. Y., Chun, L. M., Shi, B. L., Hua, Y. W., Sheng, Z., Hai, N. G., Ji, F. S., Hong, L. C., Yun, Q. Q. \& Lan, J. L. (2020). Clinical findings in a group of patients infected with the 2019 novel coronavirus (SARS-cov-2) outside of Wuhan, China: Retrospective case series. British Medical Journal, 368. http://dx.doi.org/10.1136/bmj.m606 